\title{
Exploring Pull Factors of Travel Motivation: An Exploratory Study in Sylhet Region
}

\author{
Fathema Farjana Hani
}

Lecturer, Department of Business Administration, North East University Bangladesh, Telihaor, Sheikhghat, Sylhet-3100, BANGLADESH

*E-mail for correspondence: farjanahani@ gmail.com

Received: Jan 12, 2016

Accepted: Feb 11, 2016

\begin{abstract}
Bangladesh has a massive potential to flourish its tourism sector. As it have spectacular resources to present. This study analyzes the importance level of motivational pull factors that affect tourists' decision when they chose a destination for tourism. 100 questionnaires were completed using face-to-face and telephone interview to collect pre and post-visit information. Data have gathered from the tourists who visited from outside of Sylhet and also from greater Sylhet Division by structured questionnaires. The study demonstrates that highest importance level gained by the availability of public toilet in the tourist spot (mean value 4.64). Gradual importance is attained from the elements- easily reached and cleanliness of the destination, pleasant and safe accommodation, personal security, prices of different products, availability of hygiene food and beverages, availability of recreation facilities, reasonable rent of accommodation, and shopping facility After examining the post visit opinion found some elements are treated the negative e.g. price of various products (food, drink, handicrafts, etc.), availability of public toilet, availability of different recreation facility (Water Park, sports facility, night life, etc.), and shopping facility. This study has an extensive implication for further research in tourism.
\end{abstract}

Keywords: Tourism, Pull factors, Importance level, Negative elements, Sylhet Division JEL Classification Code: L83

\section{INTRODUCTION}

Bangladesh is abundant with its cultural, historical, archeological, natural and spiritual resources. Every part of it consists of diverse form of appealing potential. These potential can be utilized for the development of tourism sector. As tourism is a leisure and recreational movement, sometimes it happens due to necessity. Tourism is the very promising tool for development which also creates employment opportunity for unemployed. Infrastructural development, awareness, and proper policy can bring effective change in this country of panoramic beauty. A destination opens the outlet to present existing heritage and breed foreign exchange. According to Rahman et al. (2010), Bangladesh is bestowed with beautiful coasts and beaches, archeological sites, historical and religious places, hills and islands, forests and jungles and attractive countryside with innumerable water bodies and green fields of agriculture.

Sylhet is the north eastern part of Bangladesh and adorned with eye-catching beauty of tea gardens, fragrance of oranges, lemons and pineapples. The greater Sylhet (Sylhet, Moulvibazar, Sunamgong and Habigong administrative district) region is decorated with rivers, waterfalls, hills and mountains, parks, hotels and resorts, tea gardens. There are different tribes e.g. Chakma, Monipuri, Tipra, Khasia etc. with their distinct and colorful culture.

Tourism sector of this region (Sylhet), in spite of having huge potential, is somehow facing the problem of getting the number of domestic and foreign tourists. It seems Sylhet is treated less highly than it deserves to be by the potential tourists, national policymakers and other stakeholders. In this case, proper understanding of the existing (positive and negative) image of Sylhet can help to plan and implement for further development of this potential sector. (Akter \& Hamid, 2013)

Knowledge about which factors the tourists are giving importance in choosing the destination is very much important for attracting domestic and foreign tourists. Infrastructural development should be fitted to the expectation of tourists. Many service and product industries are related with the tourism activity. If the country can uplift its tourism sector, the related sector of product and service can gain advancement also.

In nature greater Sylhet is adorned with mighty rivers like Surma, Kushiara, Khwuai, Monu, and Piang; hills and mountains of Moulvi Bazar, Jaflong, and Volagong; 
waterfalls like Madhabkundo, Porikunda and Hamham; distinguished Lawachara National park (largest rain forest of Asia with more than 500 rare species like Gibbons, owls, leopard, python); spacious tea states and gardens of Srimongal, Hobigong, and Sylhet. (Shawon, 2013)

According to Haque \& Islam (2015) tourismis not only a concept of enjoyment or travelling or passing the holidays, but also a development concept and it has now been placed a wider significance among the mass people, government and development planner in Bangladesh.

\section{LITERATURE REVIEW}

"Motivation is the driving force within individuals that impels them to action. This driving force produced by a state of tension, which exists as the result of an unfulfilled need." (Schiffman \& Kanuk, 2009, p. 103).

According to (Lubbe, 1998) people's motivations to travel start when they become aware of certain needs and perceive that certain destinations may have the ability to serve those needs.

Dann (1997) present the motivational forces as push and pull forces leading people to travel. The push forces are related to the desire to travel of the tourist while pull forces are associated with the qualities of the destination which tend to attract the tourist.

Fodness (1994) opines that while motivation is only one of many variables shaping tourism behavior, it is commonly acknowledged by tourism professionals and academics alike that it is a critical variable because it is the driving force behind all variables.

There are different studies regarding travel motivation of different authors. Motivation creates psychological force to human to act. So, motivation is the pivotal point to explain tourist behavior clearly. Khuong \& Ha (2014) opines that travel motivation, including internal or psychological motives (push factor) and external motives of the destination attribute (pull factor) positively affected tourist satisfaction of destination, as well as their return intention to this place in the future. Also this research finding indicated that pull factor had more significant effect on tourists' destination satisfaction and their return intention than push factor.

Kassean \& Gassita (2013) states that an understanding the factors that influence peoples' choice of their holiday destinations can play a key role in planning activities more practically by the tourism authority.

Sangpikul (2007) applied the push and pull motivations to investigate travel motivations of Japanese senior travelers to Thailand. He used the push and pulls theory to explain underlying concepts of why travelers opt for a particular destination and viewed salient features of both travelers from different market segments and the destination.
According to (Crompton \& Mckay, 1997) there are three key reasons for putting in effort on tourist motivation research:

- First, motives are the key to designing offerings for tourists

- Second, motives directly relate to the subsequent satisfaction that the tourist assesses

- Finally, identifying and prioritizing motives allows tourism marketers and planners to understand visitors' decision processes.

Yuan \& McDonald's (1990) conduct a study on motivations for overseas travel from four countries: Japan, France, West Germany and the UK.

The nature and extent of the reciprocal relationship between push and pull factors of motivations for pleasure travel by using data from Canadian Tourism Attribute and Motivation Survey Studied by (Uysal \& Jurowski, 1993).

According to (Mohammad \& Som, 2010) demand refers to motives (push factors) that sustain tourists' desire while supply relates to destinations characteristics (pull factors).

Swarbrooke \& Horner (2005) states the importance of the range of motivators related to consumers in the tourism industry, which could be categorized into those motivating a person to take a particular holiday to a specific destination.

Tourism is a recreational activity which may be individually or gregariously; may for the only advent or doing a specific task; either it is domestic or international or a door step for acquaintance with different culture and nationality. The innate need for tourism can force by the specific destinations attractiveness and specialty. Knowledge about the external motivation (related to the destination) of a tourist which is immense for developing tourism destination as well as attracting domestic and foreign tourists.

\section{ObJectives}

This study was conducted to identify the profile of the tourists who were visiting the tourism destination(s) of Sylhet region. Pull factors of travel motivation are most likely contribute in the image formation of a destination. Because these factors are completely place based. The purpose of this study was to assess the importance level of pull factors to the tourist when they consider a destination for tourism and also finding the experience of these factors as satisfaction level. To reach in outcome pre and post visit counsels of the tourists have been analyzed to find out the positive contributor and negative contributor of a destination image. 


\section{MetHodology}

As the purpose of the research was to gain insight of their (tourists) attitudinal approach regarding the tourist spots of Sylhet region, multiple elements were used to complete this. The elements/variables were selected based on the knowledge from the extensive literature review. A survey on the tourists from greater Sylhet region and outside of the Sylhet Division conducted. Interviews conducted at different hotels, tourists' spots, and rail and bus stations of greater Sylhet Division. Convenience sampling was used in this study. Total 125 tourists were contacted for data collection. All of who were answered the questionnaire at the first meeting. At the first meeting they answered the importance level of the pull elements with their socio-demographic and tour related information. But among them, 100 of the respondents were managed who answered the questionnaire (both pre and post-trip) after visiting the spots as post-trip satisfaction level regarding the pull factors. During the first meeting the 125 respondents were met face-to-face. Among 100 of respondents who answered both times were met face-to-face (72 respondents) and also over the phone (28 respondents). Data collection period was spread over two months (October \& November). Both primary and secondary data and information were used in this study. The sources of secondary data were books, articles, journals, etc. Primary data collected from the survey by structured questionnaire. The questionnaire was divided into two parts. The first part focused on accomplishing the objective to find out the profile and tour related information of the tourists. The second part was to achieve another objective of exploring pull factors. In the second part of the questionnaire, a five point Likert Scale was used to point the pull factors' importance level and satisfaction. Both qualitative and quantitative approach was used to collect the data. In the study, some tabular analyses have been used for processing and analyzing the data. With the help of software packages (MS word, MS Excel), the tabulated data were analyzed by using Sum, Standard Deviation, Mean, Percentage, etc.

\section{RESEARCH FINDINGS}

Table 1: Socio-Demographic Profile of the Respondents

\begin{tabular}{|l|c|c|c|}
\hline Variables & Sub-Variables & Frequency & $\%$ \\
\hline Gender & Male & 66 & 66 \\
\cline { 2 - 4 } & Female & 34 & 34 \\
\cline { 2 - 4 } & Total & 100 & 100 \\
\hline \multirow{4}{*}{ Age } & $1-15$ & 3 & 3 \\
\cline { 2 - 4 } & $16-25$ & 57 & 57 \\
\cline { 2 - 4 } & $26-35$ & 25 & 25 \\
\cline { 2 - 4 } & $36-46$ & 10 & 10 \\
\cline { 2 - 4 } & $46-$ above & 5 & 5 \\
\cline { 2 - 4 } & Total & 100 & 100 \\
\hline \multirow{4}{*}{\begin{tabular}{l} 
Sarital \\
\cline { 2 - 4 }
\end{tabular}} & Married & 33 & 33 \\
\cline { 2 - 4 } & Unmarried & 67 & 67 \\
\cline { 2 - 4 } & Total & 100 & 100 \\
\hline
\end{tabular}

\begin{tabular}{|c|c|c|c|}
\hline \multirow[t]{6}{*}{$\begin{array}{l}\text { Level of } \\
\text { Education }\end{array}$} & $\begin{array}{l}\text { Primary } \\
\text { Education }\end{array}$ & 3 & 3 \\
\hline & $\begin{array}{l}\text { Secondary } \\
\text { Education }\end{array}$ & 9 & 9 \\
\hline & Higher Secondary & 32 & 32 \\
\hline & Graduate & 41 & 41 \\
\hline & Post Graduate & 15 & 15 \\
\hline & Total & 100 & 100 \\
\hline \multirow{8}{*}{$\begin{array}{l}\text { Occupational } \\
\text { Level }\end{array}$} & Students & 52 & 52 \\
\hline & Housewives & 13 & 13 \\
\hline & Private Service & 9 & 9 \\
\hline & Govt. Service & 16 & 16 \\
\hline & Unemployed & 4 & 4 \\
\hline & Self-employed & 6 & 6 \\
\hline & Retired & 0 & 0 \\
\hline & Total & 100 & 100 \\
\hline \multirow{9}{*}{$\begin{array}{l}\text { From } \\
\text { Geographic } \\
\text { area }\end{array}$} & Sylhet & 28 & 28 \\
\hline & Barishal & 3 & 3 \\
\hline & Khulna & 12 & 12 \\
\hline & Dhaka & 25 & 25 \\
\hline & Rajshahi & 16 & 16 \\
\hline & Rangpur & 3 & 3 \\
\hline & Mymensingh & 4 & 4 \\
\hline & Chittagong & 9 & 9 \\
\hline & Total & 100 & 100 \\
\hline
\end{tabular}

Source: Calculated from Primary Data

Table 1, shows that majority of the respondents are male $(66 \%)$, and about one-third are female $(34 \%)$. Their age group indicates, $57 \%$ respondents belong to the $16-25$ groups. Most of them are students visiting with friends or family or individually. The age group 26-35 contains $25 \%$ of the tourists who are mainly visiting with family or for business/official purpose noticed. Age group 36-45 holds $10 \%$ of the respondents. Group 1-15, 46-above represent minor portion $3 \%$ and $5 \%$ of the respondents respectively. Most of the tourists are unmarried (67\%). Only 33\% are married. In the level of education the study shows, the majority of the tourists are graduate $(41 \%)$ and holding higher secondary (32\%) education. $15 \%$ are post graduate. Primary and Secondary education containa small portion of the tourists as $3 \%$ and $9 \%$ respectively. Among the respondents only $4 \%$ were unemployed, and no tourist was found retired. Self-employed consists of $6 \%$. Onefourth of the respondents are service holders (Govt. service-16\%, Private service-9\%). The number of young tourist comprise of students were the largest group (52\%), which indicate above half of the respondents. $13 \%$ of the tourists were housewives. Mostly they were visiting with their family. $28 \%$ of the tourists were from greater Sylhet region. A good number represent Dhaka Division (25\% of the tourist). A Study conducted by Akter \& Hamid (2012), also found that out of 120 respondents $28.33 \%$ were from Dhaka. The third largest portion imparted by Rajshahi Division with $16 \%$ of the tourists. Rest of the division represent small portion. 
Barisal and Rangpur contained same percentage like 3\%. The tourist from Mymensingh and Chittagong were $4 \%$ and 9\% respectively. A tourist from Rangpur said that "It is a long distance to visit Sylhet from Rangpur and also there related huge transportation and accommodation cost."

Table 2: Tour Related Information

\begin{tabular}{|c|c|c|c|}
\hline Variables & Sub-Variables & Frequency & $\%$ \\
\hline Sources of & Friends/Relatives & 43 & 43 \\
\cline { 2 - 4 } Information & Magazines & 2 & 2 \\
\cline { 2 - 4 } & Television/Radio & 10 & 10 \\
\cline { 2 - 4 } & Internet/Social sites & 24 & 24 \\
\cline { 2 - 4 } & Newspapers & 9 & 9 \\
\cline { 2 - 4 } & $\begin{array}{c}\text { Tour Operator/ } \\
\text { Travel Agency }\end{array}$ & 12 & 12 \\
\hline \multirow{4}{*}{\begin{tabular}{c} 
Purpose Visit \\
\cline { 2 - 4 }
\end{tabular}} & Total & 100 & 100 \\
\cline { 2 - 4 } & Visiting/Touring & 35 & 35 \\
\cline { 2 - 4 } & Business Purpose & 6 & 6 \\
\cline { 2 - 4 } & Official Tour & 12 & 12 \\
\cline { 2 - 4 } & Study Tour & 25 & 25 \\
\cline { 2 - 4 } & Religious/Spiritual & 22 & 22 \\
\cline { 2 - 4 } & Total & 100 & 100 \\
\hline
\end{tabular}

Source: Calculated from Primary Data
Akter \& Hamid (2012) found that friends and relatives are the main and credible source to the most of the tourists. Here, also the respondents' primary source of information was from friends/relatives (43\%). Second largest source of information was from social sites/internet $(24 \%)$ as the people are becoming learned about internet. $10 \%$ of the tourists were exposed of television/radio as the source of information. Printed media (magazines and newspaper) represents smaller portion $2 \%$ and $9 \%$ respectively. Tour operator and travel agency have not been mentioned dependable and feasible source of information. "Generally, the consumer receives the most information about a product from commercial sources-those controlled by the marketer. The most effective sources, however, tend to be personal." (Kotler et.al. 2011, p. 132)

In response to the purpose of visit $35 \%$ of the respondents express visiting/touring were their purpose. The second largest portion was for study tour. As Sylhet is renowned for spiritual thought $22 \%$ of the respondents were for religious/spiritual motive. Official tour and business purpose consist of 12\%, $6 \%$ respectively.

\section{Responses regarding Pull Factors}

Table: 3a: Importance level of the elements (Pre-visit)

\begin{tabular}{|c|c|c|c|c|c|c|c|}
\hline \multirow[t]{2}{*}{ Elements } & \multicolumn{5}{|c|}{ How important is this element? } & \multirow[b]{2}{*}{ Mean ${ }^{1}$} & \multirow[b]{2}{*}{$\mathrm{SD}^{1}$} \\
\hline & V.I & I. & Neu & Un. I & Com. Un. & & \\
\hline 1. Easily reached destination & 56 & 37 & 7 & 0 & 0 & 4.49 & 0.62 \\
\hline 2. Cleanliness of the destination & 52 & 44 & 4 & 0 & 0 & 4.48 & 0.57 \\
\hline 3. Availability of hygiene food \& beverages & 36 & 40 & 16 & 8 & 0 & 4.04 & 0.92 \\
\hline 4. Pleasant and safe accommodation & 45 & 38 & 16 & 1 & 0 & 4.27 & 0.76 \\
\hline 5. Personal security & 44 & 34 & 16 & 5 & 1 & 4.15 & 0.93 \\
\hline 6. Reasonable rent of accommodation in the destinations & 22 & 49 & 25 & 3 & 1 & 3.88 & 0.81 \\
\hline $\begin{array}{l}\text { 7. Price of different products } \\
\text { (food, drink, handicrafts etc.) are reasonable }\end{array}$ & 29 & 55 & 14 & 2 & 0 & 4.11 & 0.70 \\
\hline 8. Availability of public toilet & 77 & 14 & 7 & 0 & 2 & 4.64 & 0.78 \\
\hline $\begin{array}{l}\text { 9. Availability of different recreation facility } \\
\text { (water park, sports facility, night life etc.) }\end{array}$ & 30 & 47 & 20 & 2 & 1 & 4.03 & 0.82 \\
\hline 10. Shopping facility & 14 & 39 & 27 & 16 & 4 & 3.43 & 1.04 \\
\hline
\end{tabular}

Source: Calculated from primary data

Note: V.I- Very Important, I- Important, Neu-Neutral, Un. I- Unimportant, Com. I- Completely Unimportant. Using Likert Scale (very important=5, important=4, Neutral=3, Unimportant=2, Completely unimportant=1).

Mean $^{1}$ value greater than the midpoint of 5 or 2.50 indicates the respondents are in the range Neutral to Very Important.
Smaller SD ${ }^{1}$ (Standard Deviation) indicates lower dispersion among the responses in each element. 
Table 3b: The experiences (Post-visit) after visiting destinations.

\begin{tabular}{|c|c|c|c|c|c|c|c|}
\hline \multirow[t]{2}{*}{ Elements } & \multicolumn{5}{|c|}{ Your experience about this element? } & & \\
\hline & V.S & Sa. & $\mathrm{Neu}$ & Dis. & V. Dis. & $\mathrm{Mean}^{2}$ & $\mathrm{SD}^{2}$ \\
\hline 1. Easily reached destination & 18 & 54 & 16 & 12 & 0 & 3.78 & 0.88 \\
\hline 2. Cleanliness of the destination & 14 & 49 & 23 & 14 & 0 & 3.63 & 0.89 \\
\hline 3. Availability of hygiene food \& beverages & 7 & 39 & 29 & 23 & 2 & 3.26 & 0.96 \\
\hline 4. Pleasant and safe accommodation & 7 & 41 & 31 & 15 & 6 & 3.28 & 1.00 \\
\hline 5. Personal security & 10 & 29 & 33 & 27 & 1 & 3.2 & 0.98 \\
\hline $\begin{array}{l}\text { 6. Reasonable rent of accommodation } \\
\text { in the destinations }\end{array}$ & 9 & 41 & 27 & 22 & 1 & 3.35 & 0.95 \\
\hline $\begin{array}{l}\text { 7. Price of different products } \\
\text { (food, drink, handicrafts etc.) are reasonable }\end{array}$ & 0 & 14 & 26 & 50 & 10 & 2.44 & 0.85 \\
\hline 8. Availability of public toilet & 0 & 5 & 13 & 58 & 24 & 1.99 & 0.75 \\
\hline $\begin{array}{l}\text { 9. Availability of different recreation facility } \\
\text { (water park, sports facility, night life etc.) }\end{array}$ & 3 & 13 & 30 & 36 & 18 & 2.47 & 1.02 \\
\hline 10. Shopping facility & 14 & 54 & 15 & 13 & 4 & 2.39 & 1.01 \\
\hline
\end{tabular}

Source: Calculated from primary data

Note: V.S- Very Satisfied, Sa- Satisfied, Neu-Neutral, Dis- Dissatisfied, V. Dis- Very Dissatisfied. Using Likert Scale (Very satisfied=5, satisfied=4, Neutral=3, Dissatisfied=2, Very Dissatisfied=1).

Mean ${ }^{2}$ value greater than the midpoint of 5 or 2.50 indicates the respondents are in the range Neutral to Very Satisfied.SmallerSD2 (Standard Deviation) indicates lower dispersion among the responses in each element.

Tourism is related to different types of transportation (Table $3 a$ and $3 b$ ). Different places are landed by various types of conduction. Every tourist wants safe and lenient journey. So, the element 'Easily reached destination' gain mean value 4.49. Here, the Standard Deviation 0.62 indicates lower variance among the respondents. But the experience regarding this element contains mean value 3.78 and Standard Deviation 0.88. Although above half of the respondents is satisfied. Cleanliness and hygienic food and beverages are a prerequisite for sound trip. The mean value and Standard Deviation of the element 'Cleanliness of the destination' (4.48, 0.57) and 'Availability of hygienic food and beverages' (4.04, 0.92) indicate importance of these factors. In contrast the mean value of experience regarding these elements consist 3.63 and 3.26 respectively. The Standard Deviation 0.89 and 0.96 indicate the lower variance among the respondents. Pleasant and safe accommodation was very important to 45 of the respondents important to 38 of the respondents. The mean value 4.27 and Standard Deviation 0.76 pressing the importance level. 41 of the respondents were satisfied with accommodation facility. Mean and standard Deviation is 3.28 and 1.00 respectively. One of the respondents expressed that "comfortable and easeful accommodation make the trip more fascinating."

Reasonable rent of accommodation is important by 49 of the respondents. A good number of tourists also mention it as very important (22). Mean value (3.88) and Standard Deviation (0.81) represent this. But 9 of the respondents were very satisfied and 41 were satisfied with accommodations rent in Sylhet region. Mean value 3.35 and Standard deviation is 0.95 of this element. In response to the element price of different products e.g. food, drink, handicrafts are reasonable in Sylhet region, above half of the respondents mentioned it as the important element for choosing tourist destination. In contrast half of the respondents expressed their dissatisfaction regarding this element. Mean value (2.44) and Standard Deviation (0.85) indicate the condition. Overall tourists are satisfied with the rent of accommodation but they are dissatisfied with the price of different products.

Availability and genial public toilet in the tourist spots is essential for male, female and children. 77 of the respondents expressed it as very important element for choosing tourism destination. Here mean value 4.64 and Standard Deviation 0.78. 58 of the tourist were dissatisfied with this element as touring different destination of Sylhet region. Mean value 1.99 and Standard Deviation 0.75 reveal the dissatisfaction level. Mainly tourism is a recreational activity and it accumulates several types of activity to gain delectation. Availability of different recreation facility is very important to 30 andimportant to 47 of the respondents. Here mean value 4.03 and Standard deviation 0.82. But 36 of the tourists are dissatisfied and 18 are very dissatisfied with this element. Mean value 2.47 and Standard Deviation is 1.02. That means recreational facility is scarce in sylhet. For increasing tourist flow in Sylhet, it is obligate to creating proper recreational facility. One of the tourists expresses that "there are lack of night life enjoyment facility. Because about nothing to see or involved in night stay."

Variety seeker tourists want to shop around to find out their preferable thing. Shopping facility is important because product of different tourist places is the representatives of this place and carries promotion. Shopping facility is important to 39 of the tourists. Mean value is 3.43 and 
Standard Deviation is 1.04 . As 54 of the tourists were satisfied with existing shopping facility the mean value is 2.39 and Standard Deviation is 1.01. To make this satisfied tourist very satisfied the shopping facility should improve.

From the opinion of the tourists found some positive contributor and negative contributor to the existing image of Sylhet.

It can be summarized as follows:

\begin{tabular}{|c|c|}
\hline & \\
\hline $\begin{array}{l}\text { - } \text { Easily reached destination } \\
\text { - Cleanliness of the } \\
\text { destination } \\
\text { - Availability of hygiene } \\
\text { food \& beverages } \\
\text { - Pleasant and safe } \\
\text { accommodation } \\
\text { - Personal security } \\
\text { - Reasonable rent of } \\
\text { accommodation in the } \\
\text { destinations }\end{array}$ & 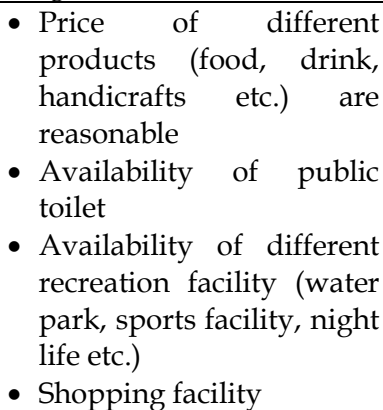 \\
\hline
\end{tabular}

These positive and negative contributors are especially form pull factors. Pull factors are particularly related with the destination. By analyzing the pull factors the tourism marketer can take step for destination image formation. To uplift Sylhet as a tourism destination the proper authority has to turn the negative contributor into positive and improve the positive contributor also.

\section{CONCLUSION}

This study can be helpful to exploit the pull factors of travel motivation. Also will be conducive to answer the questionswhy tourist chose specific destination for tourism? Which factors the tourists weigh to choose a place for tourism? Proper knowledge about the pull factors assists the tourism marketer to build their destination image. As the people always want a good return to their money and match the expenditure to the product/service quality.

Overall analysis shows that the existing positive factors of pull motivation are greater that negative factors. It is expectant to work out the plans for creating a veritable change positively. Exceptional natural and made beauty should be exposed to attract tourists. For the betterment of overall tourism sector of Bangladesh proper initiatives is required from concerned authority.

The motivation behind conducting this research was contribute in the tourism literature. As the data of this study is derived from a small sample and collected from some selected areas of the region, this can be regarded as tentative. Further research can include wide sample or include another areas of the country. According to Das \& Chakraborty (2012), Tourism offers immense potentiality for employment generation, poverty alleviation and maintaining ecological balance. It is relatively a modern phenomenon, which plays an intensely important role in the economic development of any country.

\section{REFERENCES}

Akter, M. B. \& Hamid, M. A. (2012). “The Image of Sylhet as a Tourist Destination: An Empirical Study." SIU Studies. Vol.3, No. II. p.37-46.

Akter, M. B. \& Hamid, M. A. (2013).“Expectation Versus Satisfaction Level of the Tourists of Sylhet Region". Bangladesh Research Publications Journal. Vol. 9, Issue 1. p. 15-21.

Crompton, J. L. \& Mckay, S. L. (1997), “Motives of Visitors Attending Festival Events." Annals of Tourism Research. Vol. 24 (2). p. 425-436.

Dann, G. (1997). “Anomie, Ego-enhancement and Tourism." Annals of Tourism Research.Vol.4(4). p. 184-194.

Das, R. K. \&Chakraborty, J. (2012), “An Evaluation Study on Tourism in Bangladesh." DevelopingCountry Studies.Vol.2, No. 1. p. 17-27.

Fodness, D. (1994). "Measuring tourist motivation." Annals of Tourism Research.Vol.21(3). p. 555-581.

Haque, M. A. \& Islam, F. (2015). “Problems and Prospects of Tourism Industry at Sylhet Region in Bangladesh". IOSR Journal of Research \& Method in Education.Vol. 5, Issue 5. p. 23-32.

Kassean, H. \& Gassita, R. (2013), “Exploring Tourists Push and Pull Motivations to Visit Mauritius as a Tourist Destination." African Journal of Hospitality, Tourism and Leisure.Vol.2 (3). p. 1-13.

Khuong, M. N. \& Ha, H. T. (2014), “The Influence of Push and Pull Factors on the International Leisure Tourists' Return Intention to Ho Chi Minh City, Vietnam- A Mediation Analysis of Destination Satisfaction". International Journal of Trade, Economics, and Finance. Vol.5, No 6. p. 490-496.

Kotler, P. at. el. (2011), Principles of Marketing: A South Asian Perspective. $13^{\text {th }}$ Ed. Dorling Kindersley (India) Pvt. Ltd.

Lubbe, B. (1998). "Primary Image as a Dimension of Destination Image: An Empirical Assessment." Journal of Travel and Tourism Marketing, Vol. 7 (4). Pp. 21-43.

Mohammad, B. A. \&Som, A. P. (2010).“An Analysis of Push and Pull Travel Motivation of Foreign Tourists to Jordan." International Journal of Business and Management. Vol.5, No.12, p. 41-50.

Rahman, M. L., Hossain, S. M. Miti, S. S., Kamal, A. K. (2010). "An Overview of Present Status and Future Prospects of the Tourism Sector in Bangladesh".Journal of Bangladesh Institute of Planners. Vol. 3 (December 2010). P. 65-75.

Sangpikul, A. (2007). “A Factor-Cluster Analysis of Tourist Motivations: A Case of U.S. Senior Travellers." Original Scientific Paper. Vol.56 (1). p. 23-40.

Schiffman, L. G. \&Kanuk, L. L. (2009), Consumer Behavior, 9'th Ed. Dorling Kindersley (India) Pvt. Ltd.

Shawan, S. S. (2013). Exploring the Issues and Challenges in Tourism Business: A Study Based on Sylhet. Dept. of Business Administration, Shahjalal University of Science and Technology.Sylhet: Submitted as Master Thesis. (Unpublished)

Swarbrooke, J. \& Horner, S. (2005). Consumer Behavior in Tourism. $1^{\text {st }}$ ed. Burlington: Elsevier Butterworth-Heinemann.

Uysal, M. \&Jurowski, C. (1993). "An Empirical Testing of the Push and Pull Factors of Tourist Motivations." Annals of Tourism Research. Vol. 21 (4). p. 844-846.

Yuan, S. \& McDonald, C. (1990). “Motivational Determinants of International Pleasure Time." Journal of Travel Research. Vol. 24 (1). p. $42-44$.

$$
--0 \text {-- }
$$

